\title{
https://doi.org/10.46813/2021-136-135 \\ METHODS OF ADJUSTING FORMING LINES USING A LOW VOLTAGE THYRISTOR SWITCH
}

\author{
O.I. Kosoi, V.O. Mats, V.V. Mytrochenko, V.Yu. Titov, Yu.D. Tur, I.O. Chertishchev \\ National Science Center "Kharkov Institute of Physics and Technology", Kharkiv, Ukraine \\ E-mail: Kosoy@kipt.kharkov.ua
}

A method of adjusting the generating lines of a high-voltage pulse modulator with a thyristor switch at a charging voltage of $150 \mathrm{~V}$ is given. The degree of pre-distortion is determined to obtain in the operating mode $(60 \mathrm{kV})$ a voltage pulse with the required non-uniformity at the optimal value of the degaussing current of the transformer. An element of fine tuning of forming lines at operating voltage is developed and applied.

PACS: $27.19+\mathrm{W}$

\section{INTRODUCTION}

At the National Science Center "Kharkov Institute of Physics and Technology" there are charged particle accelerators, which are used for scientific and technological purposes. The system of pulsed high-voltage supply of klystrons is the most energy-intensive in the technological accelerator. This system is based on a linear circuit of a high-voltage modulator with a resonant charge of the PFN and its subsequent discharge through a thyratron switch to a pulse transformer of high-voltage power supply of amplifying klystrons [1].

The efficiency of high-voltage pulse modulators is determined by two main factors: heat loss in the modulator systems and the level of pulse formation on the secondary winding of the pulse transformer closest to the rectangular (molding efficiency). Ensuring sufficiently small distortions of the pulse shape is one of the requirements for a pulse transformer. These distortions are due to the influence of the inductance of the primary winding, the scattering inductance and the capacitances of the transformer windings. Therefore, special attention is paid to the shape of the pulse and methods of its correction. The use of a pulse transformer leads to distortion of the pulse shape [2].

The scattering inductance and the inductance of the supply ends influence the formation of the pulse front. As the scattering inductance increases, the pulse front is tightened. When using a pulse transformer, the most real duration of the pulse front will be $1.2 \ldots 1.5 \mu \mathrm{s}$. The magnetization inductance of the pulse transformer affects the bevel of the pulse top. As the magnetization inductance decreases, the pulse bevel increases. The magnetization inductance is determined by the design parameters of the pulse transformer, as well as the degaussing current of the transformer. Adjustment of the peak of the voltage pulse is carried out by adjusting the forming line.

But when operating the process accelerator in nominal mode, it is difficult to adjust the forming line.

The paper considers the method of adjusting the pulse from the PFN at low voltages.

\section{EXPERIMENTAL INSTALLATION}

Fig. 1 shows a block diagram of a klystron modulator. Three-phase alternating voltage supplied to the stepup transformer (1) with a built-in three-phase rectifier. The transformer is a power supply for the modulatorrectified voltage up to $35 \mathrm{kV}$. A single-phase oil-cooled charging choke (2) with charging diodes connected to a rectifier is a modulator charger. The inductance of the choke is equal to $\mathrm{L}=3.2 \mathrm{H}$.

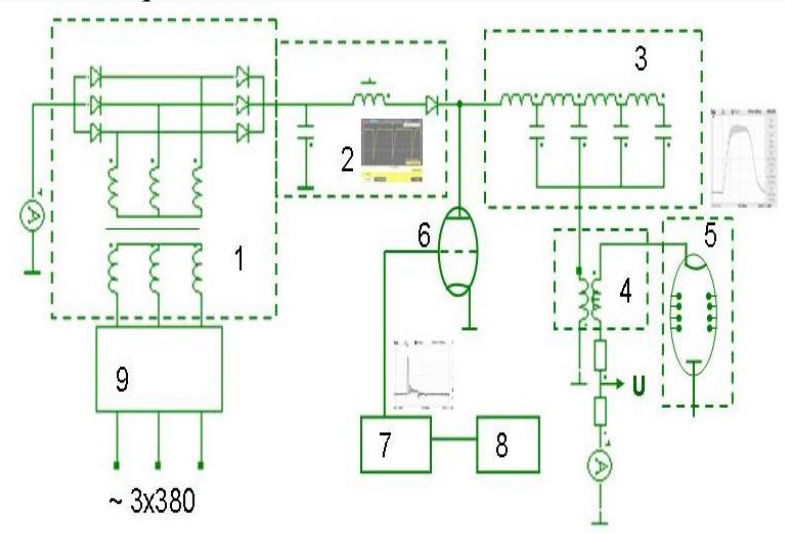

Fig. 1. Block diagram of the klystron modulator:

1 -transformer-rectifier; 2 - charging circuit;

3 -PFN; 4 -pulse transformer; 5 -klystron;

6 -thyratron; 7 -trigger unit; 8 -synchronization unit; 9 -voltage regulator

The rectified voltage is regulated by a thyristor regulator (9), which simultaneously performs the function of a voltage stabilizer. This voltage is proportional to the input voltage, it is fed through the charging choke to the PFN (3). The pulse transformer has a transformation coefficient $n=13$ (4). It increases the voltage of the PFN to the operating value. To obtain the maximum increment of the induction of the transformer core is demagnetized with a current of 5...15 A. The resistance of the pulse transformer is a klystron KIU-12AM with a beam resistance of $1700 \Omega(5)$.

Thiratron TGI 1-2500/50 is used as a switch to discharge the PFN to the pulse transformer (6). These thyratrons allow switching current up to $2.5 \mathrm{kA}$ at anode voltage up to $50 \mathrm{kV}$. The trigger unit of the thyratron (7) generates a voltage pulse on its grid with an amplitude of $1 \ldots 1.5 \mathrm{kV}$ and a duration of $2 \ldots 2.5 \mu \mathrm{s}$. The sync pulse generating unit (8) supplies a voltage pulse with an amplitude of $15 \mathrm{~V}$ to the synchronization input of the start unit.

The most important elements that determine the efficiency of pulse generation in the linear circuit of a highvoltage modulator are the generating line and the pulse transformer. The obligatory condition is coordination of wave resistances and a possibility of work of elements at big average capacities. 
PFNs used in modulators of technological accelerators SRE "Accelerator" are divided into two types. The first is a single PFN, it folds of 10 capacitors $(\mathrm{C}=0.03 \mu \mathrm{F}) \quad$ connected by variable inductors $(\mathrm{L} \approx 2 \ldots 4 \mu \mathrm{H})$. The characteristic resistance the second is a double PFN with a characteristic resistance of $60 \Omega$, which consists of $2 \times 12$ capacitors with a capacity of $0.0036 \mu \mathrm{F}$ connected by variable inductors $(\mathrm{L} \approx 2 \ldots 4 \mu \mathrm{H})$.
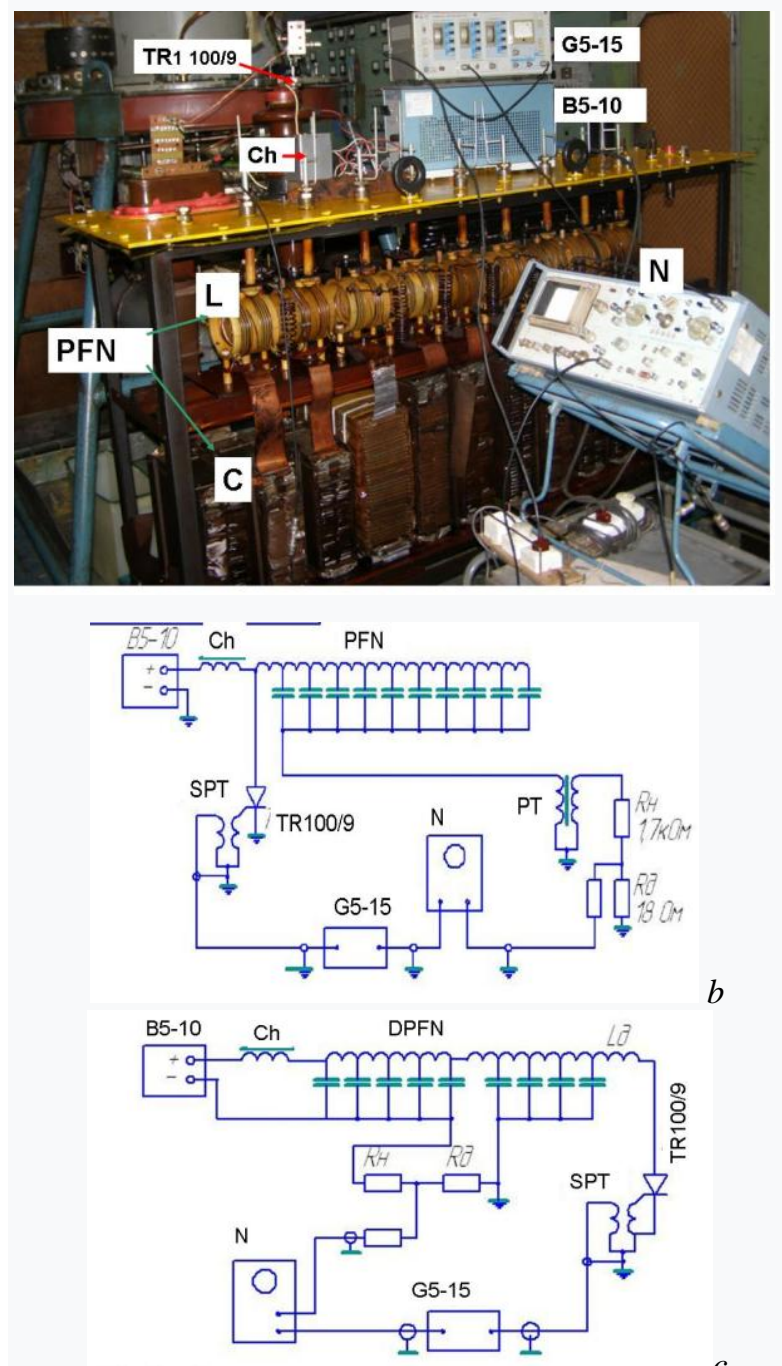

$b$

Fig. 2. Appearance of measuring the voltage pulse at the output of a single PFN (a); is a diagram of measuring the voltage pulse at the output of a single $P F N(b)$; is a diagram of measuring the voltage pulse at the output of a double PFN (c)

Fig. 2,a,b show diagrams for measuring the voltage pulse at the output of the PFN.

The purpose of the measurements is to adjust and refine the parameters of the pulses at low voltage, as well as the selection of line elements to obtain a pulse in a shape close to rectangular on the secondary winding of the transformer.

To charge the PFN (PFN, DPFN) power supply B510 (55-10) is used, the charging voltage is $150 \ldots 300 \mathrm{~V}$. The charge is through a choke $\mathrm{Ch}$ with an inductance of $4 \mathrm{H}$. The thyristor TR100/9 (TP100/9) is used as a switch. The sync-pulse is supplied from the generator G5-15 (Г5-15). The voltage pulse at the output of the line on the resistance of $1.7 \mathrm{k} \Omega$ is recorded by a digital oscilloscope $(\mathrm{N})$ through a divider with a factor of 100 .

\section{EXPERIMENTS FOR FORMATION OF A VOLTAGE PULSE}

Fig. 3,a,b shows the voltage pulses of the PFN on the resistance of $1700 \Omega$ at a charging voltage of $150 \mathrm{~V}$. The duration of the front of the single PFN was $0.5 \mu \mathrm{s}$, the duration of the decline is $1 \mu \mathrm{s}$, the pulse duration is $3.5 \mu \mathrm{s}$, when using a double PFN the duration of the front is $0.35 \mu \mathrm{s}$, the duration of the decline is $0.5 \mu \mathrm{s}$ with a pulse duration of $2.6 \ldots 2,8 \mu \mathrm{s}$. The figure shows that excluding the influence of the pulse transformer we obtain voltage pulses in shape close to rectangular. The rectangularity factor for the pulses was $\sim 85 \%$.

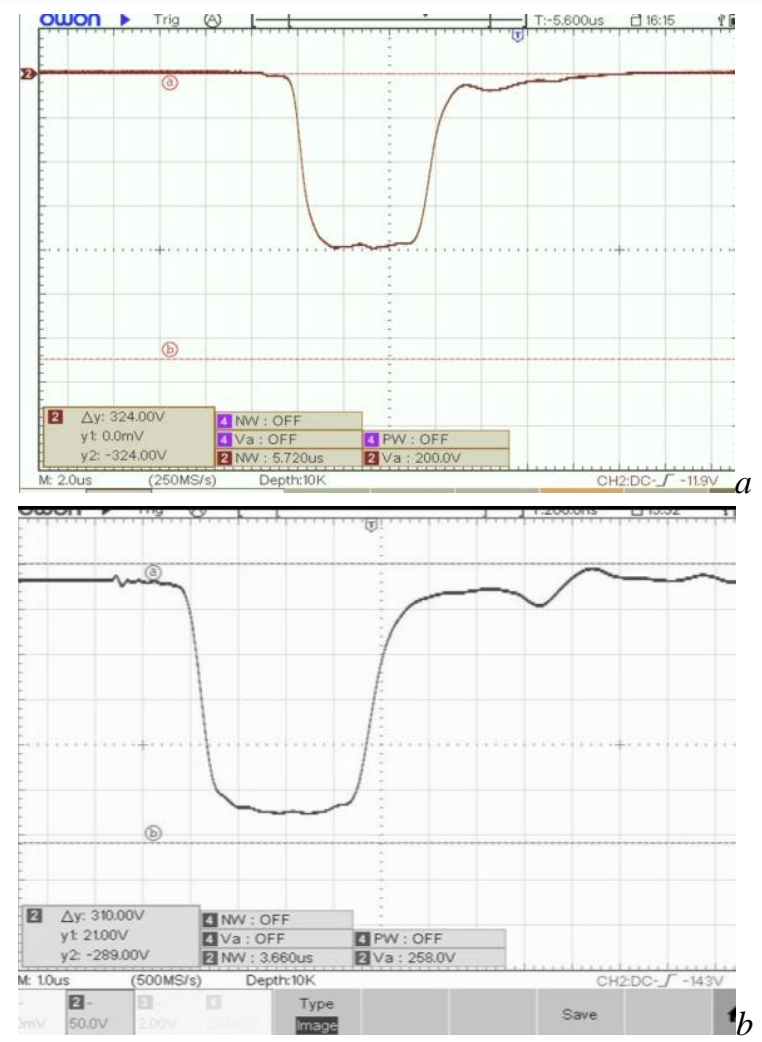

Fig. 3. Voltage pulses of the PFN at the active resistance of $1700 \Omega$ pulses PFN (a); pulses duble PFN (b)

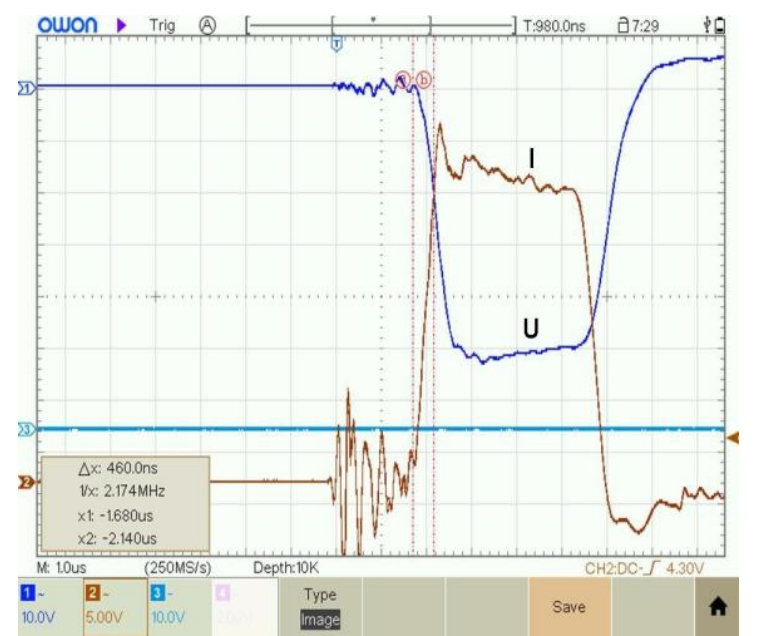

Fig. 4. Voltage $(U)$ and current (I) pulse on the secondary winding of the pulse transformer of the technological accelerator LINAC-40: $15 \mathrm{~A} / \mathrm{div}, 30 \mathrm{kV} / \mathrm{div}, 1 \mu \mathrm{S} / \mathrm{div}$

Fig. 4 shows the voltage pulse on the secondary winding of the pulse transformer of the process accelerator LINAC-40. A double PFN with a impedance of ISSN 1562-6016. BAHT. 2021. №6(136) 
$60 \Omega$ was used. The bevel of the top of the pulse was quite large and amounted to $10 \%$. The figure illustrates the need for additional tuning of the line pulse, which must be performed at low voltage.

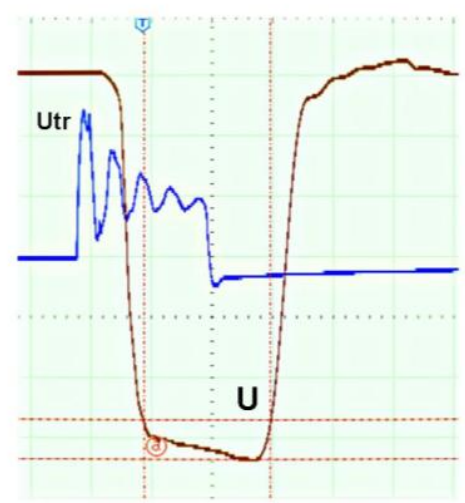

Fig. 5. Voltage pulse at the output of the forming line with overcorrection (U) $20 \mathrm{~V} / d i v$, voltage pulse trigger (Utr) $10 \mathrm{~V} / \mathrm{div} 2 \mu \mathrm{S} / \mathrm{div}$

Fig. 5 shows the voltage pulse at the active resistance of $1.7 \mathrm{k} \Omega$ (see Fig. 2) using overcorrection. The meaning of the adjustment is to intentionally distort the shape of the pulse on the active resistance so that when it is fed to the primary winding of the pulse transformer on the secondary winding a new pulse is formed. The shape of this pulse should look like a rectangle. Distortion of the pulse shape is achieved by changing the values of inductance in the cells of the PFN.

Fig. 6 shows the voltage pulse on the secondary winding of the transformer after correction. The figure shows that when adjusting the voltage pulse, the rectangularity factor increases. The bevel of the top was $\pm 1 \%$. The pulse front was $1.1 \mu \mathrm{s}$, the decline was $1.5 \mu \mathrm{s}$, the pulse duration was $2.85 \mu \mathrm{s}$. Thus, the rectangularity of the pulse is $\sim 75 \%$. For the use of a circuit with a pulse transformer, this is quite a good indicator, but with the help of additional adjustment of the cells of the forming line, it is possible to improve the rectangularity factor. For example, the duration of the pulse front can be reduced by reducing the inductance of the supply contacts, which represent an additional inductance of the first cell of the PFN.

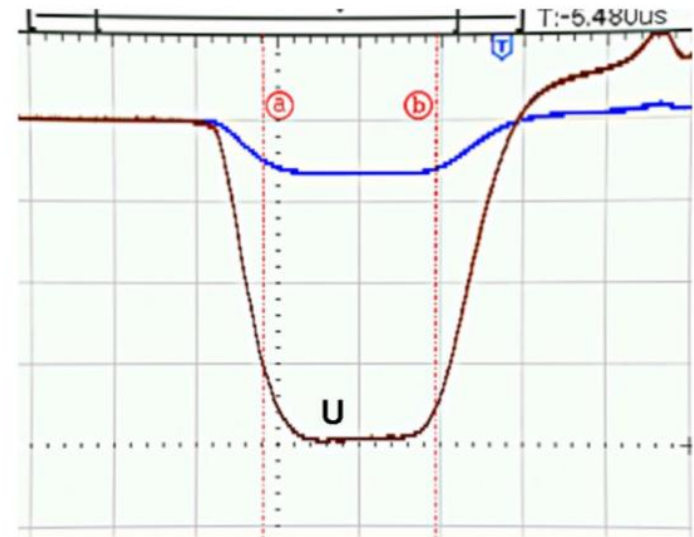

Fig. 6. Pulse on the secondary winding of the pulse transformer after adjustment (U). $30 \mathrm{kV} / d i v, 2 \mu \mathrm{S} /$ div

It is also possible to adjust the shape of the voltage pulse by introducing a ferrimagnetic material into the inductors of the PFN, thus changing the value of the inductance (Fig. 7). The coil in the line is wound on an insulating pipe with a diameter of $50 \mathrm{~mm}$. The pipe has an outlet to the upper cover of the PFN so it is possible to lower into it and move along the coils of the ferrite rings or rods. This movement can be done even with the high-voltage modulator running. Thus, it is possible to adjust the pulse directly during the operation of the process accelerator.

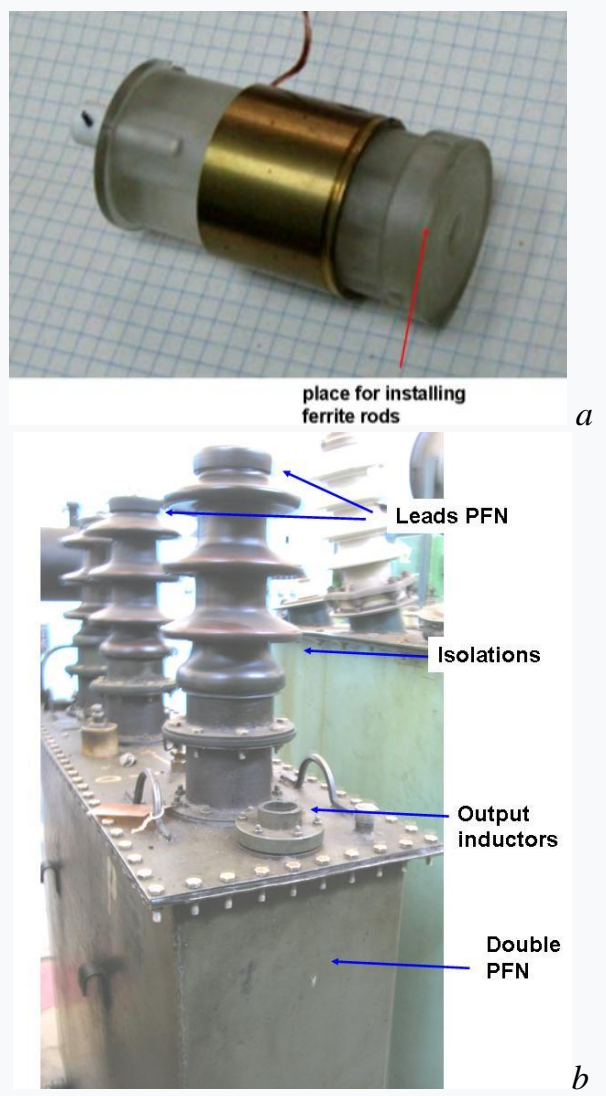

Fig. 7. Device for moving ferromagnetic rods along the inductors of the forming line (a), and appearance double PFN (b)

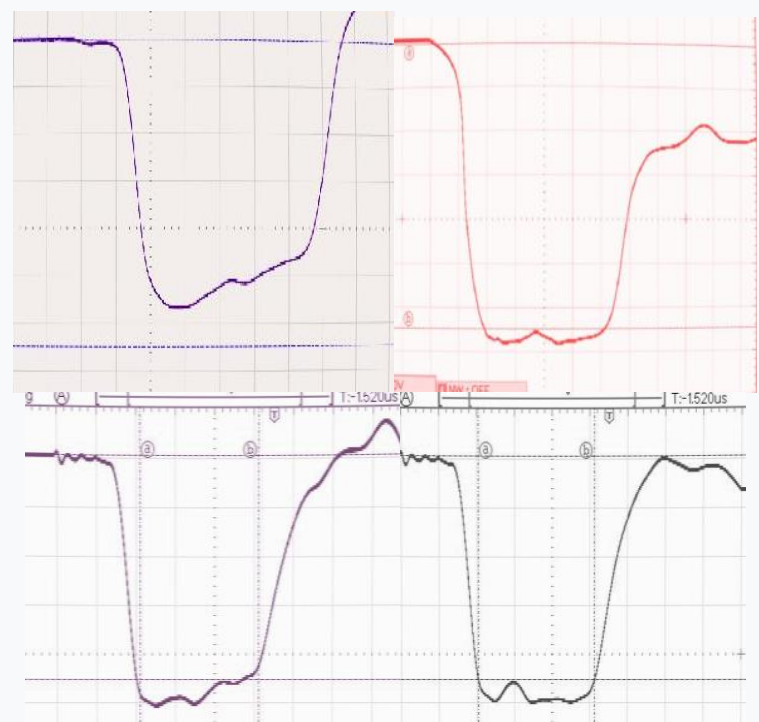

Fig. 8. Voltage pulses on the secondary winding of the pulse transformer when adjusting the values of line inductance

Fig. 8 shows the voltage pulses at different positions of the ferrite rods. The figure illustrates the ability to adjust the shape of the pulse in a fairly vast range. 
Fig. 9 shows the voltage pulse at the output of the modulator before and after correction and selection of the parameters of the cells forming the line. The figure shows that it is possible to obtain a pulse in shape close to rectangular in the existing process accelerators.

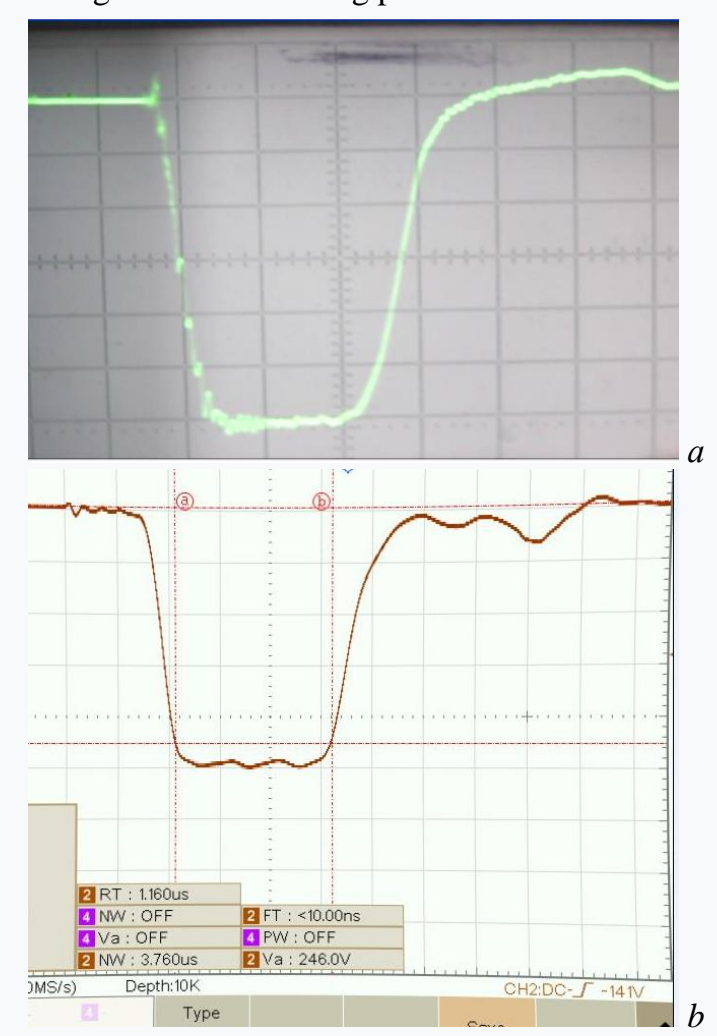

Fig. 9. Voltage pulse at the output of the modulator: regularity factor $0.75(a)$; coefficient of rectangularity 0.8. $30 \mathrm{kV} / \mathrm{div}, 1 \mu \mathrm{S} / \mathrm{div}(\mathrm{b})$

\section{CONCLUSIONS}

1. Works on adjustment of PFNs on technological accelerators KUT-1, EPOS, LINAC-10, LINAC-40 are carried out.

2. Measured voltage pulses on the primary and secondary windings of the pulse transformer.

3. The influence of the pulse transformer on the shape of the voltage pulse is studied.

4. The possibility of adjusting the voltage pulse in a fairly wide range is shown.

\section{REFERENCES}

1. V.I. Beloglazov, I.A. Chertyshchev, I.A. Chaika, A.I. Kosoi, D.A. Kapliy, V.P. Romasko, V.Yu. Titov, Yu.D. Tur. Design and exploitation powerful thyratron swith in modulators accelerators NSC KIPT // Problems of Atomic Science and Technology. Series "Nuclear Physics Investigations". 2016, № 3, p. 50-53.

2. O.I. Kosoy, V.O. Matz, V.P. Romasko, Yu.A. Titarenko, V.Yu. Tytov, D.V. Titov, Yu.D. Tur, I.O. Chaika, I.A. Chertishchev, E.A. Yaroshenko. Assessment of energy efficiency of high-voltage LUE modulators // Problems of Atomic Science and Technology. Series "Nuclear Physics Investigations”. 2020, № 3, p. 49-52.

Article received 07.10.2021

\section{МЕТОДИКА НАСТРОЙКИ ФОРМИРУЮЩИХ ЛИНИЙ С ИСПОЛЬЗОВАНИЕМ НИЗКОВОЛЬТНОГО ТИРИСТОРНОГО КЛЮЧА}

\section{А.И. Косой, В.А. Мац, В.В. Митроченко, В.Ю. Титов, Ю.Д. Тур, И.А. Чертищев}

Приведен способ настройки формирующих линий мощного высоковольтного импульсного модулятора с помощью тиристорного ключа при заданном напряжении 150 В. Метод заключается в ведении в форму импульса модулятора при низком напряжении предискажений с целью получения высоковольтного импульса с плоской вершиной при рабочем напряжении. Определено предискажение для получения в рабочем режиме (60 кВ) импульса напряжения с необходимой неоднородностью при оптимальной величине тока размагничивания трансформатора. Разработан и использован элемент точной настройки формирующих линий при рабочем напряжении.

\section{МЕТОДИКА НАЛАШТУВАННЯ ФОРМУЮЧИХ ЛІНЙ З ВИКОРИСТАННЯМ НИЗЬКОВОЛЬТНОГО ТИРИСТОРНОГО КЛЮЧА}

\section{О.І. Косой, В.О. Мац, В.В. Мітроченко, В.Ю. Титов, Ю.Д. Тур, І.О. Чертіщев}

Приведено спосіб налаштування формуючих ліній потужного високовольтного імпульсного модулятора за допомогою тиристорного ключа при зарядній напрузі 150 В. Метод полягає у введенні у форму імпульсу модулятора при низькій напрузі передспотворень з метою отримання високовольтного імпульсу з плоскою вершиною при робочій напрузі. Визначено передспотворення для отримання в робочому режимі (60 кВ) імпульсу напруги з необхідною нерівномірністю при оптимальній величині струму розмагнічування трансформатора. Розроблено та застосовано елемент точного налаштування формуючих ліній при робочій напру3i. 